\title{
Observations from a nationwide vigilance program in medical care for spinal muscular atrophy patients in Chile
}

\author{
Atrofia muscular espinal en Chile, resultados de un programa de atención médica nacional \\ Karin ALVAREZ1', Bernardita SUAREZZ2, María Angélica PALOMINO3 ${ }^{3}$, Cecilia HERVIAS ${ }^{4}$, Giancarlo \\ CALCAGNO4, Maripaz MARTINEZ-JALILIEF, Andrés LOZANO-ARANGO², Susana LILLO6, Mariana HARO', \\ Fanny CORTÉS ${ }^{3}$, Samuel PANTOJA7, Andrés CHAHIN? , Paulina ORELLANA ${ }^{1}$, Jorge A. BEVILACQUA ${ }^{8}$, \\ Enrico BERTINI ${ }^{9}$, Claudia CASTIGLIONI²
}

\begin{abstract}
Spinal muscular atrophy (SMA) has gained much attention in the last few years because of the approval of the first intrathecal treatment for this neurodegenerative disease. Latin America needs to develop the demographics of SMA, timely access to diagnosis, and appropriate following of the standards of care recommendations for patients. These are essential steps to guide health policies. Methods: This was a descriptive study of a cohort of SMA patients from all over Chile. We analyzed the clinical, motor functional, and social data, as well as the care status of nutritional, respiratory and skeletal conditions. We also measured the SMN2 copy number in this population. Results: We recruited 92 patients: 50 male; 23 SMA type-1, 36 SMA type-2 and 33 SMA type-3. The median age at genetic diagnosis was 5, 24 and 132 months. We evaluated the SMN2 copy number in 57 patients. The SMA type-1 patients were tracheostomized and fed by gastrostomy in a $69.6 \%$ of cases, $65 \%$ of SMA type-2 patients received nocturnal noninvasive ventilation, and $37 \%$ of the whole cohort underwent scoliosis surgery. Conclusion: Ventilatory care for SMA type-1 is still based mainly on tracheostomy. This Chilean cohort of SMA patients had timely access to genetic diagnosis, ventilatory assistance, nutritional support, and scoliosis surgery. In this series, SMA type-1 is underrepresented, probably due to restrictions in access to early diagnosis and the high and early mortality rate.
\end{abstract}

Keywords: Spinal muscular atrophy; Latin America; demography; Standard of care; SMN1

\section{RESUMÉN}

La Atrofia Muscular Espinal (AME) ha concitado mucha atención en los últimos 2 años debido a la aprobación del primer tratamiento intratecal para esta enfermedad neurodegenerativa. América Latina necesita desarrollar la demografía de AME, un acceso oportuno al diagnóstico y un seguimiento apropiado de los pacientes que incorporen los estándares de atención recomendados por expertos. Estos son pasos esenciales para orientar las futuras políticas de salud en esta enfermedad. Métodos: Este es un estudio descriptivo de una cohorte de pacientes con AME de todo el país. Se analizaron los datos clínicos, motores, funcionales, sociales y el estado nutricional, respiratorio y esquelético de los pacientes. También medimos el número de copias del gen SMN2 en esta población. Resultados: se reclutaron 92 pacientes, 50 varones; 23 AME tipo 1, 36 AME tipo 2 y 33 AME tipo 3. La edad media al diagnóstico genético fue de 5, 24 y 132 meses respectivamente. Evaluamos el número de copias de SMN2 en 57 pacientes. Un 69,6\% de los pacientes con AME tipo 1 estaban traqueostomízados y gastrostomizados, un $65 \%$ de los pacientes con AME tipo 2 usaban ventilación nocturna no invasiva y el 37\% de toda la cohorte presentaba una cirugía de escoliosis. Conclusión: Esta cohorte chilena de pacientes con AME tuvo acceso oportuno al diagnóstico genético, asistencia ventilatoria, apoyo nutricional y cirugía de escoliosis, sin embargo, la atención ventilatoria para AME tipo 1 continúa aun basándose principalmente en la traqueostomía. En esta serie, AME tipo 1 está subrepresentada, probablemente debido a las restricciones en el acceso al diagnóstico temprano y la tasa de mortalidad alta y temprana.

Palabras clave: atrofia muscular espinal; América Latina; demografía; nivel de atención; SMN1

\footnotetext{
'Clínica Las Condes, Laboratorio de Biología Molecular y Oncología, Santiago, Chile;

${ }^{2}$ Clínica Las Condes, Departamento de Neurología Pediátrica, Santiago, Chile;

${ }^{3}$ Clínica Las Condes, Departamento de Pediatría, Santiago, Chile

${ }^{4}$ Clínica Las Condes, Servicio de Kinesioterapia, Santiago, Chile.

${ }^{5}$ Clínica Las Condes, Unidad de Investigación Clínica, Dirección Académica, Santiago, Chile

${ }^{6}$ Clínica Las Condes, Departamento de Medicina Física, Santiago, Chile

${ }^{7}$ Clínica Las Condes, Departamento de Ortopedia y Traumatología, Santiago, Chile

${ }^{8}$ Universidad de Chile, Hospital Clínico, Departamento de Neurología y Neurocirugía, Santiago, Chile;

${ }^{9}$ Bambino Gesù Children Hospital, Unit of Neurodegenerative and Neuromuscular Disease, Rome, Italy.

Claudia Castiglioni iD https://orcid.org/0000-0002-1981-7550
}

Correspondence: Claudia Castiglioni; Departamento de Neurología Pediátrica, Clínica Las Condes; Lo Fontecilla 441; Postal code: 7591046 , Las Condes.

Santiago Chile; E-mail: ccastiglioni@clc.cl

Conflict of interest: There is no conflict of interest to declare.

Support: This work has been funded by Clínica Las Condes, Academic Research Office, PIDA-2014-002 to CC and KA.

Disclosure: Biogen had an opportunity to review and provide feedback on the manuscript.

Received 01 February 2019; Received in final form 13 March 2019; Accepted 24 March 2019 
Spinal muscular atrophy (SMA) is an autosomal recessive neuromuscular disorder characterized by degeneration of the motor neurons in the spinal cord and the lower portion of the brainstem, leading to progressive proximal muscular atrophy and weakness. The disease is caused by insufficient levels of survival of motor neuron (SMN) protein due to the homozygous deletion of the SMN1 gene in $95-98 \%$ of patients ${ }^{1}$. The estimated prevalence is about 1-2/100,000 persons with an incidence of 1/10,000 live births ${ }^{2}$. In humans, the telomeric SMN1 has an almost-identical centromeric gene called $S M N 2$. A single nucleotide difference on exon 7 of SMN2 affects the splicing and leads to a truncated protein that is rapidly degraded. There is an inverse correlation between the number of $S M N 2$ copies and the severity of illness ${ }^{3}$. Thereby, SMN2 constitutes a modifier of disease severity that has an important role in prognosis.

There are four main SMA types: type 1, type 2, type 3 and type 4 , based on the degree of functional severity and age at symptom onset, and subtypes are additionally defined for SMA type 1 and $3^{4,5}$.

Currently, there is a lack of data addressing the degree of compliance to standards of care recommendations and timely access to diagnosis in Latin America, as well as the clinical and demographic characteristics and medical care status of patients with SMA ${ }^{6,7,8}$. Clear demographic information, reduced time to diagnosis, and access to quality health care across geographically and economically diverse countries will allow a better delineation of challenges and needs of the Latin American SMA community.

In this context, and particularly for this study, Chile recently joined the Organization for Economic Cooperation and Development; Chile is an upper-middle-income country, with a per capita gross domestic product of 21,030 USD with a median monthly revenue of 772 USD, and life expectancy at birth is 78.8 years 9 . The National Health Insurance System provides $80 \%$ of medical care while private insurance supplies $20 \%^{10}$.

Since 2006, a molecular genetic study has been accessible in our country, which allows confirmation of the homozygous $S M N 1$ deletion in patients suspected of having SMA ${ }^{11,12}$. Despite this development, in Chile there are still unmet needs in the field of molecular testing for the diagnosis of genetic conditions, with a paucity of laboratories and resources required to perform molecular genetic analyses ${ }^{13}$.

Every country needs to build precise information about patients with SMA, the leading genetic cause of infant mortality worldwide, to improve biomedical research and timely access to standard clinical care. The recent approval of nusinersen, and other treatments that will follow, has stressed the need for epidemiological data in order to plan health care and budget impact ${ }^{1415,16}$.

Here we report, for the first time, an observational study in a nationwide cohort of SMA patients, aiming to describe their clinical, social and molecular data. In addition, patients were assessed for their nutritional, respiratory and skeletal conditions during their follow-up at our center.

\section{METHODS}

\section{Patient recruitment}

The SMA patients were recruited consecutively between 2012 and 2016, as part of a nationwide vigilance program of SMA status, with the support of an institutional research grant funding. We identified patients referred by professional health care workers across Chile, from patient organizations, and from the medical records of routinely followed patients in our outpatient motor disorders program. The patients were recruited through the family association for SMA, (FAME Chile), a well-coordinated social organization that has succeeded in enrolling a significant number of SMA patients all over the country. As well, we sent emails to several physiotherapists, physiatrists and pediatric neurologists from neurological and rehabilitation centers throughout the countryside. All the patients were evaluated at the same center in Santiago.

The reference center is a private medical and academic hospital. The patient evaluation was done by the staff of the Neuromuscular and Motor Disorder Program of the Pediatric Neurology Department and Kinesiotherapy Service. The data were collected from the first year of recruitment until the end of 2016, and the analysis of all the data was done during 2017.

We collected demographic, clinical, motor functional and epidemiological data from this population. We included all the patients with already-confirmed homozygous SMN1 deletion and performed a molecular genetic analysis in those who had a clinical phenotype suggesting SMA with electrophysiological studies, or a muscle biopsy indicating an anterior horn cell disorder. We analyzed the SMN2 copy number in patients who consented to participate. We obtained data about social status, educational level and family income through a survey conducted by a social worker. The poverty threshold was considered to be $50 \%$ of the median income as defined by the Organization for Economic Cooperation and Development ${ }^{17}$.

\section{Informed consent}

Informed consent was obtained from the adult patients and parents or legal guardian of child patients prior to the study and following a full explanation of the procedures included in the study. Children older than 12 years of age were asked to assent. The institutional ethical committee approved the study.

\section{Patient assessment}

Expert neurologists in neuromuscular disease obtained clinically relevant data and examined the patients every six months. Two expert physiotherapists, trained in functional 
motor scales, evaluated patients who consented to participate, using the Hammersmith (HFMS) and Motor Function Measure (MFM-32) for patients from 6-60 years of age and the short version MFM-20, for children older than three years and under six years of age. These two evaluations were performed on the same day for each patient ${ }^{18,19,20}$. Spearman's rank correlation coefficients evaluated correlations between the MFM-32 and HFMS for nonambulant patients.

\section{Molecular study}

After receiving the informed consent, we obtained a peripheral blood sample to extract genomic DNA from patients, and to assess the number of copies of SMN1 and $S M N 2$. The DNA was isolated from a whole blood sample using the Wizard Genomic DNA Purification Kit (Promega, USA) to assess the number of copies of SMN1 and SMN2 by multiplex ligation-dependent probe amplification (MLPA) analysis. The MLPA kit P60-B2 (MRC Holland, Amsterdam, The Netherlands) was used according to the manufacturer's recommendations. Polymerase chain reaction (PCR) products were analyzed on an ABIPRISM 3100 capillary sequencer and Peak scanner v1.0 software. The data obtained were analyzed by using the Coffalyser software v.8 (MRC-Holland, Amsterdam, The Netherlands). Two independent experiments were performed to confirm results obtained by MLPA analysis.

\section{RESULTS}

\section{Demographic data}

The overall number of patients initially recruited was 115 . We excluded seven patients because the MLPA showed two SMN1 copies, and another 16 patients because a blood sample was not available. Finally, 92 patients were definitively classified as SMA harboring a homozygous deletion of SMN1, 50 of whom were males. The age range of SMA subtypes and the number of deceased patients during the follow-up is shown in Figure 1. The age range of 10-19 years was the most prevalent among patients with SMA types 2 and 3. The median age at genetic diagnosis for SMA types 1, 2 and 3 was 5, 24 and 132 months, respectively. We did not identify any patients with SMA type 4, the adult form of SMA.

Table 1 summarizes the median age by SMA types, relevant clinical data, the status of ventilatory and nutritional support, the proportion of patients who had scoliosis surgery, the SMN2 copy number and the mean values of functional motor scales.

Six out of 23 patients with SMA type 1 died at a mean age of eight months, all of whom belonged to the type $1 \mathrm{~b}$ subclass $^{5}$. All but one of the 17 surviving SMA type 1 patients had been given a tracheostomy and were still alive at publication date. Only one SMA type 2 patient died at eight years old due to pneumonia. The patients with SMA type 3 are all currently alive.

Seven out of 85 families (8.2\%) had two children affected by the disease and 26 patients $(31 \%)$ were from one-child families. Table 2 shows the SMA siblings' phenotype-genotype correlation, highlighting a discordant phenotype in some siblings.

Electromyography and muscle biopsy were done in $88 \%$ and $54 \%$ of patients, respectively, before obtaining a genetic diagnosis (Figure 2).

\section{Geographic distribution, social, educational characteristics and family income}

A total of 71 SMA families completed the survey, allowing us to collect social and household income data. Of these,

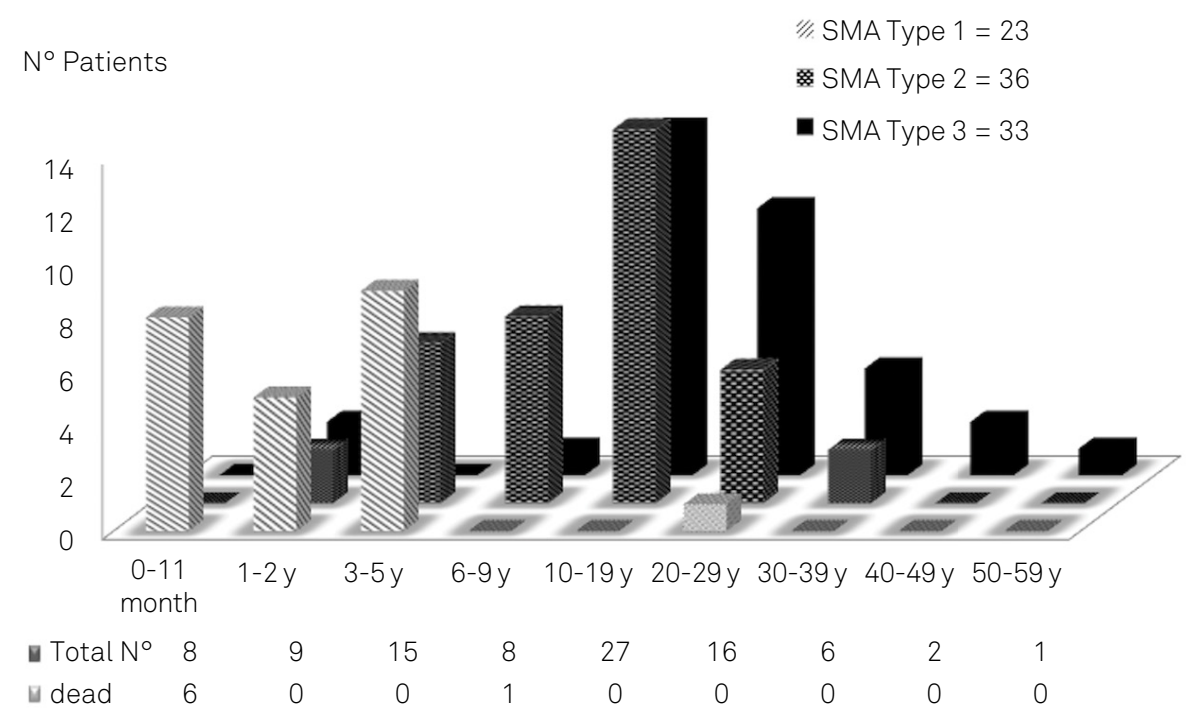

Figure 1. The number of SMA patients in different age ranges. The age range distribution for SMA type 1, 2 and 3 is showed in a different color bar. The number of patients deceased during the study period is indicated under the age range 0-11 months and 6-9 years. 
Table 1. Demographic and clinical features.

\begin{tabular}{|c|c|c|c|c|c|}
\hline & \multicolumn{2}{|c|}{ SMA type 1} & \multirow[t]{2}{*}{ SMA type 2} & \multicolumn{2}{|c|}{ SMA type 3} \\
\hline & $1 b$ & $1 \mathrm{c}$ & & $3 a$ & $3 b$ \\
\hline No & 15 & 8 & 36 & 23 & 10 \\
\hline SexM/F, n & $9 / 6$ & $4 / 4$ & $19 / 17$ & $11 / 12$ & $7 / 3$ \\
\hline Age (mo), median & 49 & 53 & 169 & 234 & 273 \\
\hline Mortality percent & $6 / 15(40 \%)$ & 0 & $1 / 36(2.8 \%)$ & 0 & 0 \\
\hline Age at symptoms onset, (mo), median (range) & 1 & $3,5(3-4)$ & $10.5(6-18)$ & $18(6-36)$ & $48(48-120)$ \\
\hline Age genetic diagnosis, (mo), median (range) & $3(1-5)$ & $9(3-228)$ & $24(9-312)$ & $66(12-588)$ & $162(72-468)$ \\
\hline Median delay in diagnosis, (mo) (range) & $2(0-4)$ & $5(0-224)$ & $14(0-301)$ & $41(0-552)$ & $108(0-348)$ \\
\hline \multicolumn{6}{|l|}{ SMN2 copy number } \\
\hline 2 & 4 & 7 & 1 & 0 & 0 \\
\hline 3 & 0 & 1 & 25 & 11 & 1 \\
\hline 4 & 0 & 0 & 0 & 0 & 7 \\
\hline $\begin{array}{l}\text { Percent receiving nutritional support, by gastrostomy / } \\
\text { by nasogastric tube }\end{array}$ & $73 / 0$ & $75 / 0$ & $6.5 / 0$ & 0 & 0 \\
\hline $\begin{array}{l}\text { Percent receiving ventilation support, by Tracheostomy and } \\
\text { ventilator/by noninvasive ventilation }\end{array}$ & 100 & $87,5 / 12,5$ & $0 / 65$ & $0 / 28$ & $0 / 10$ \\
\hline $\begin{array}{l}\text { Percent receiving both nutritional and noninvasive ventilation } \\
\text { support }\end{array}$ & 100 & 75 & 6.5 & 0 & 0 \\
\hline Percent with scoliosis surgery & & & 57.6 & 53.4 & 20 \\
\hline HFMS median range, $\mathrm{n}$ & & & $\begin{array}{c}10,5(0-27) \\
n=16\end{array}$ & $\begin{array}{c}33(10-38) \\
n=7\end{array}$ & $\begin{array}{c}40(39-40) \\
n=5\end{array}$ \\
\hline MFM-32: >6y, median, range, $n$ & & & $\begin{array}{c}46(17-47) \\
n=11\end{array}$ & & \\
\hline MFM-20: 3-6y, median, range, $n$ & & & $\begin{array}{c}31,5(25-37) \\
n=4\end{array}$ & & \\
\hline
\end{tabular}

mo: month; n: number; SMN : survival motor neuron 2; HFMS: Hammersmith Functional Motor Scale;

MFM-32: Motor Function Measure 32; MFM-20: Motor Function Measure 20

(a)

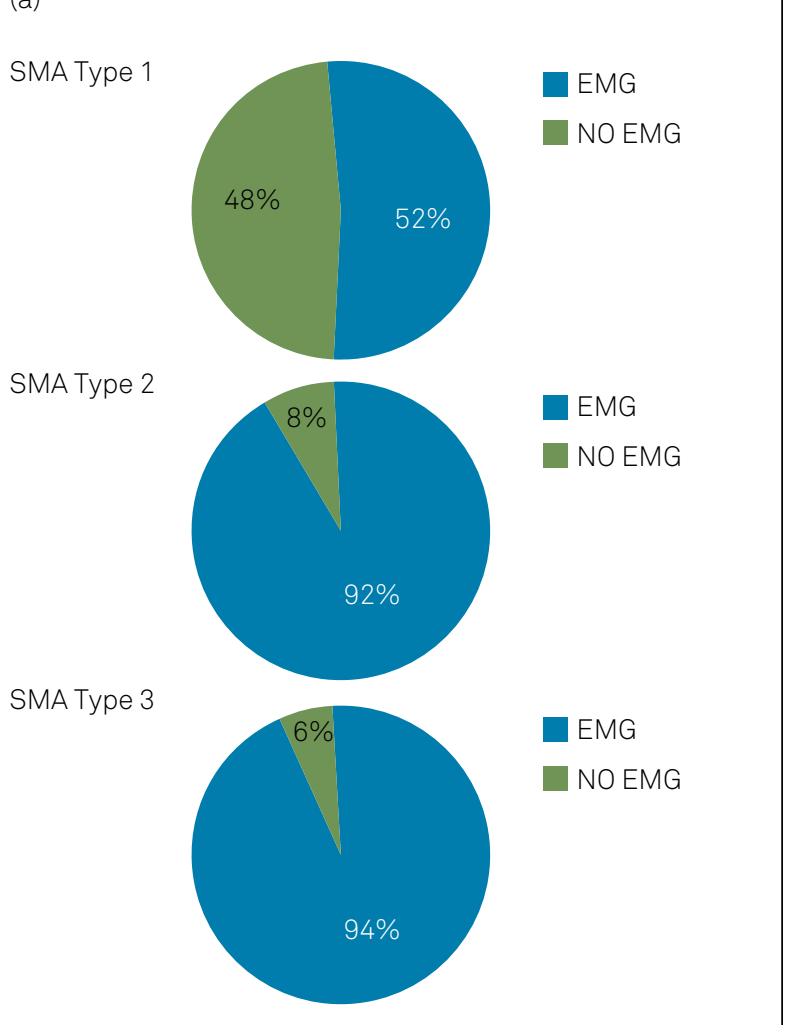

(b)

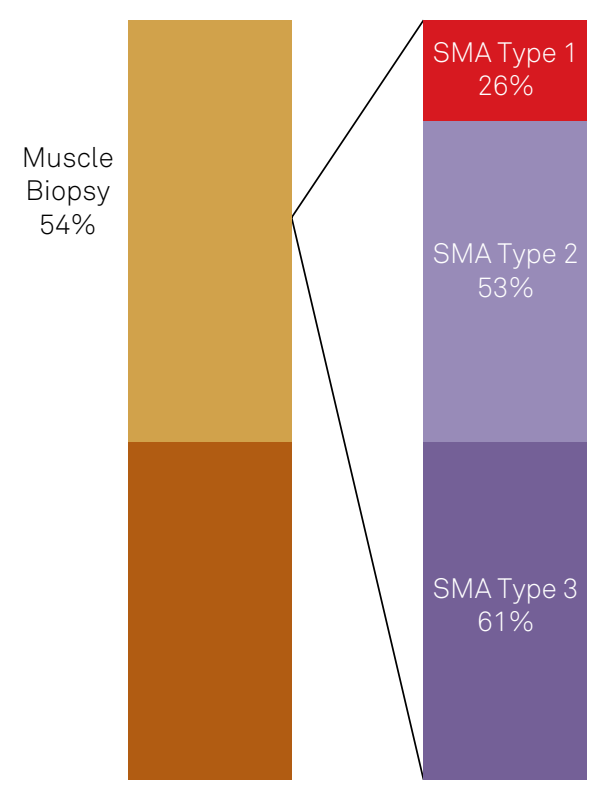

Figure 2. A. Percentage of EMG before genetic diagnosis in patients with SMA type 1,2 and 3. B. Percentage of patients with muscle biopsy before genetic diagnosis and the proportion of this procedure in each subtype of SMA 1,2 and 3 
Table 2. Phenotype and genotype characteristics of siblings with SMA.

\begin{tabular}{|c|c|c|c|c|c|c|c|c|}
\hline Family & Gender & $\begin{array}{l}\text { SMA } \\
\text { type }\end{array}$ & $\begin{array}{c}\text { Age at } \\
\text { onset } \\
\text { (months) }\end{array}$ & Initial symptoms & $\begin{array}{l}\text { Highest Motor } \\
\text { Function Achieved }\end{array}$ & $\begin{array}{l}\text { Age at loss of } \\
\text { walking }\end{array}$ & SMN2 copies & Present Age \\
\hline 1 & $\mathrm{~F}$ & 3 & 14 & Frequent falls & Unsupported walking & 11 years & 3 & 13 years \\
\hline $1^{\prime}$ & $\mathrm{F}$ & 3 & 72 & $\begin{array}{l}\text { Difficulties in } \\
\text { Sport at school } \\
\text { Hands tremor }\end{array}$ & Unsupported walking & Still ambulant & 3 & 20 years \\
\hline \multicolumn{9}{|l|}{2} \\
\hline $\begin{array}{l}\text { Monocho rionic/ } \\
\text { Biamniotic }\end{array}$ & M & 1 & 4-5 & Hypotonia & Head control & 2 & 33 months & \\
\hline \multicolumn{9}{|l|}{2} \\
\hline $\begin{array}{l}\text { Monocho. rionic/ } \\
\text { Biamniotic }\end{array}$ & M & 1 & $4-5$ & Hypotonia & Head control & 2 & 33 months & \\
\hline 3 & $\mathrm{~F}$ & 2 & $12-14$ & $\begin{array}{l}\text { Difficulties } \\
\text { in walking } \\
\text { unsupported }\end{array}$ & Walking with support & 3 & 31 years & \\
\hline 3 & M & 2 & 10 & Hypotonia & Sitting control & 3 & 26 years & \\
\hline 4 & M & 2 & 36 & Frequent falls & Independent walking & 16 years & 3 & 51 years \\
\hline 4 & $\mathrm{~F}$ & 2 & 60 & Difficult sports & Independent walking & Still walking & 3 & 39 years \\
\hline 5 & M & 3 & 60 & Frequent falls & Independent walking & Still walking & 4 & 12 years \\
\hline 5 & M & 3 & 48 & Difficulties. To run & Independent walking & Still walking & 4 & 13 years \\
\hline 6 & $M$ & 2 & 6 & Hypotonia & $\begin{array}{l}\text { Stand unsupported } \\
\text { some minutes }\end{array}$ & 3 & 4 years & \\
\hline 6 & M & 2 & 9 & Unable to stand & Sitting control & 3 & 12 years & \\
\hline 7 & $M$ & 2 & 14 & Unable to walk & Stand up supported & 3 & 9 years & \\
\hline $7^{\prime}$ & $\mathrm{F}$ & 3 & 14 & $\begin{array}{l}\text { Need support to } \\
\text { walk }\end{array}$ & Independent walking & $\begin{array}{l}\text { Still walking } \\
\text { with support }\end{array}$ & 3 & 19 months \\
\hline
\end{tabular}

$61 \%$ of patients resided in the capital city, while $39 \%$ lived throughout the rest of the Chilean regions. From this latter group, nearly $24 \%$ lived in a radius of about 200 kilometers around the capital. Eighty-five percent of families resided in urban zones versus $15 \%$ in the countryside. Fifty-three families $(75 \%)$ were recipients of the national health system. In 39 families (55\%) both parents worked and 18 (25\%) had one working parent. Twenty-eight families (39\%) were owners of their house, while five families lived in relatives' family homes. Regarding disability benefits, only $30 \%$ of the patients who were unable to walk had a powered wheelchair. The monthly income data showed that 56 families (79\%) lived on less than USD 1500/month, 16 (23\%) of whom lived below the poverty threshold ${ }^{15}$. Sixteen out of 25 adults (64\%), 10 SMA type 3 and six SMA type 2 patients, had achieved a higher education level.

\section{Molecular characterization.}

Among the 92 SMA patients, $71 \%$ had a molecular genetic confirmation at the beginning of the study, showing an SMN1 homozygous deletion of exon 7, obtained by PCR-restriction fragment length polymorphism assay. In 27 patients we performed the MLPA analysis that confirmed the homozygous deletion of SMN1. Additionally, the SMN2 copy number was analyzed in 57 patients (Table 1).

\section{Functional status.}

Eighteen (79\%) SMA type 3a patients lost the ability to walk between 18 months and 25 years of age. However, all but one of the SMA type $3 \mathrm{~b}$ individuals still maintain independent walking. Ten out of 36 (29\%) SMA type 2 patients attained motor achievements other than a seated position, i.e., crawling, standing up independently, and walking with aid. The median and range of HFMS and MFM scores for 28 and 26 SMA type 2 patients, respectively, are shown in Table 1 . The correlation between MFM-32 and HFMS in nonambulant patients was 0.733 (Figure 3)

\section{Ventilatory support.}

Forty-six patients (50\%) required ventilatory support; four patients were treated by noninvasive ventilation some months before requiring a tracheostomy, Sixteen out of 23 (69.6\%) patients with SMA type 1 had a tracheostomy. Ninety percent of SMA type 1 patients were recipients of the domiciliary national health system ventilation program; $63.9 \%$ of SMA type 2 patients used nocturnal BiPAP, $50 \%$ were supported by the national health system, and $24.3 \%$ of SMA type 3 patients received nocturnal noninvasive ventilation.

\section{Scoliosis surgery}

Thirty-three (35.9\%) patients underwent scoliosis surgery at a mean age of $11.5 \pm 3.2 \mathrm{SD}$ (range 6-19 years); 


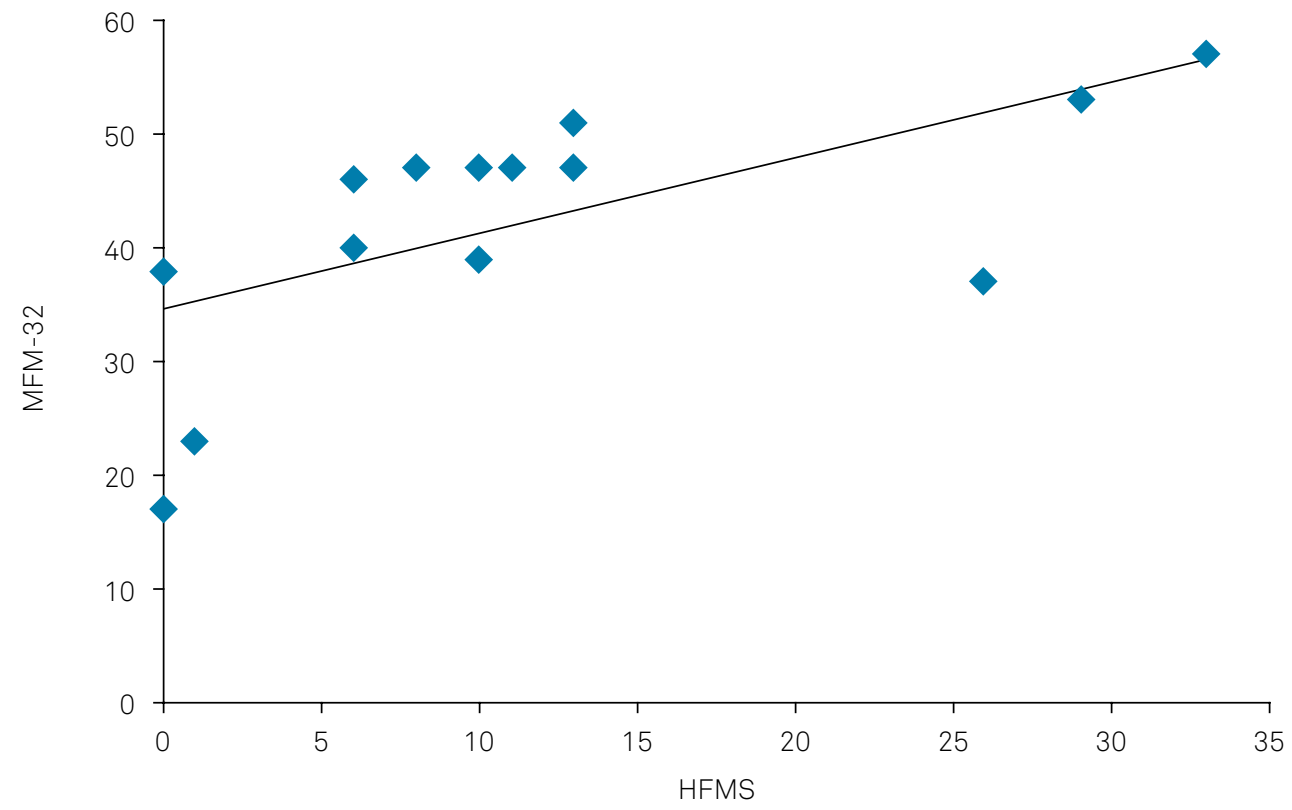

Figure 3. Correlation between MFM-32 and HFMS in non-ambulant patients with 3 copies of SMN2

$57.6 \%$ of whom were SMA type 2 patients, and $33.3 \%$ were SMA type $3 \mathrm{a}$. In 28 patients, the standard fusion procedure with arthrodesis between T2-L5 was the technique of choice with the additional support of intra-operative neural monitoring. Five children received growing rods with vertical expandable prosthetic titanium, and they were the patients who had been operated on at the youngest age (range $5-11$ years).

\section{DISCUSSION}

This comprehensive report characterizes, for the first time, a significant nationwide cohort of SMA patients in Chile. The Family Association for SMA played an important role in gathering patients as each neurological and rehabilitation service around the country only takes care of a small number of patients due to extensive geographical distribution and small population size. We estimate a prevalence between 180 and 360 patients are affected by this disorder in our country, according to the Chilean population, assuming we have a prevalence of the disease similar to most countries $^{2,21}$. The development of the MLPA to measure the SMN2 copy number allowed us to provide Chilean patients with this required genetic determination in agreement with the new recommendation guidelines. Establishing the SMN2 copy number should be routinely assessed as it is an important factor influencing the severity of the SMA phenotype and its central role for prognosis and therapeutic approaches ${ }^{22}$. The relationship between the SMA severity and the number of copies of $S M N 2$ was similar to other studies reported in different populations ${ }^{1}$.
The demographic characteristics mirrored those of the country; in our cohort, $85 \%$ reside in urban areas, and only $15 \%$ in the countryside, compared to $87 \%$ and $13 \%$, respectively, of the whole population. In our cohort, patients living in the capital city of Santiago were overrepresented at $61 \%$ vs. $40 \%$ in the national population. This fact can be easily explained by families frequently moving to the capital where they find more accessible health care and rehabilitation resources for their affected family member. However, this scenario may also account for the difficulties in getting access to clinical studies for patients living in faraway rural areas ${ }^{23}$. Regarding family structure, the percentage of single-parent families was $25 \%$ in our cohort, similar to the $27.6 \%$ of the nationwide population ${ }^{24}$. Finally, when we consider income distribution, the number of families living below the poverty threshold was $23 \%$, higher than the Organization for Economic Co-operation and Development average of $11.5 \%{ }^{17}$. The greater number of families living below the poverty threshold may be related to the need for one of the parents to stay at home without a paid job, to take care of their child. These demographic data on SMA patients and their families are certainly relevant for any umbrella program to be undertaken by a health care agency and need to be explored in further detail.

When considering clinical outcomes and results, we observed that the delay in SMA diagnosis of 5, 24 and 132 months after the onset of symptoms, shown in Table 1, was similar to the delay reported in a recent systematic literature review, that included North American and European countries, of 3.6, 14.3, and 43.6 months, for types 1,2 , and 3 respectively ${ }^{25}$. A longer waiting time to genetic diagnosis was present for patients with SMA type $3 b$, as they had been clinically diagnosed long before access to a molecular 
genetic diagnosis was available. Our cohort also showed that the length of diagnostic delay varied by the type of SMA, and there was still time wasted in search of an accurate diagnosis. The number of patients undergoing muscle biopsy and EMG before the request for genetic diagnosis well exemplifies the diagnostic odyssey many patients still experience, a practice that should be avoided following the recommendations of the SMA consensus guidelines ${ }^{26}$. The correlation found between MFM-32 and HFMS in nonambulant patients was very similar to the correlation found in a previous report ${ }^{27}$.

The age range of 10-19 years was the most represented in our cohort; similar to the recent multinational mapping of care for SMA that included 25 countries, as was the percentage of adult patients older than 20 years (27\% vs. $30 \%$ ). Also underrepresented in this registry was SMA type 1, with only $25 \%$ of the whole cohort being affected, and not nearly the $50 \%$ expected because of the known incidence of the disease $^{28}$. The severity of the disease and the higher rate of mortality could explain this percentage.

A significant difference found in our cohort, compared with the multinational mapping, was the high percentage of SMA patients on invasive or noninvasive ventilation support, representing $54.3 \%$ of our cohort compared with $12 \%$ in the multinational record; $34.8 \%$ receiving invasive ventilation vs. $29 \%$ noninvasive ventilation. The higher rate of ventilation support in our cohort may have been associated with the fact that more than $90 \%$ of patients with SMA type 1 were on invasive ventilation, and the existence of the national program for noninvasive ventilation at home, which allows rapid implementation of a complex and high burden of medical assistance for all types of SMA patients ${ }^{28}$. Invasive ventilation was restricted to SMA type 1 patients, representing $32 \%$ of all SMA patients receiving ventilatory assistance, similar to the reported $29 \%$. In contrast, only three patients with SMA type 1 were on noninvasive ventilatory support representing only $10 \%$ of all noninvasive ventilatory patients compared with $54 \%$ of the whole ventilated population. In this respect, the ventilation support approach in our country looks similar to that of Mexico, Argentina and Poland ${ }^{28}$. Perhaps a national program of standard of care of SMA patients that includes ventilatory care, and the recommendation of a BiPAP instead of tracheostomy, could improve this situation. In a country with limited and expensive access to pre-implantation diagnoses and restricted access to costly new treatments, the burden of this disease is even higher. In this context, the development of a neonatal screening would allow treatment of these patients earlier and, possibly, presymptomatically, to avoid the emotional, social and health costs of palliative treatments such as the effect of domiciliary invasive ventilation for years, and prolonged admission to the intensive care unit for acute respiratory insufficiency and infections.

Our results about the timing of scoliosis surgery add to the meager information available on this topic, although further multicenter studies and randomized clinical trials are needed to evaluate the impact of different techniques and approaches ${ }^{29}$. The recent availability of new effective treatments will increase awareness on the timely intervention in SMA, and thus a short timeframe for diagnosis is now of pivotal importance. Moreover, the standards of care guidelines that used to be useful for the best care of SMA patients are going to change, as updates now reflect pretreatment recommendations ${ }^{22,26,30,31}$.

In conclusion, our challenge is to improve earlier diagnosis, to follow the standard of care recommendations more closely and reach all the SMA patients in a country of considerable size, such as Chile, and to build monitoring programs to carefully follow-up the patients and help us establish the long-term advantages of the new upcoming therapies. Facilitating the collection of clinically meaningful data in this area is even more urgent now, when a new specific treatment has been recently approved, and others that will follow in the future have hastened the expectation for therapies by patients' families ${ }^{1416,32,33}$.

\section{Acknowledgments}

We thank the patients and families for their participation to the study and the Chilean association for SMA; FAME-Chile, for their collaboration.

\section{References} https://doi.org/10.1186/1750-1172-6-71

2. Cameron S, Jones CC, et al. Prevalence, incidence and carrier frequency of $5 q$-linked spinal muscular atrophy - a literature review. Orphanet J Rare Dis. 2017 Jul;12(1):124. https://doi.org/10.1186/s13023-017-0671-8

3. Mercuri E, Bertini E, lannaccone ST. Childhood spinal muscular atrophy: controversies and challenges. Lancet Neurol. 2012 May;11(5):443-52. https://doi.org/10.1016/S1474-4422(12)70061-3
4. Zerres K, Rudnik-Schöneborn S. Natural history in proximal spinal muscular atrophy. Clinical analysis of 445 patients and suggestions for a modification of existing classifications. Arch Neurol. 1995 May;52(5):51823. https://doi.org/10.1001/archneur.1995.00540290108025

5. Finkel RS, McDermott MP, Kaufmann P, Darras BT, Chung WK, Sproule DM, et al. Observational study of spinal muscular atrophy type I and implications for clinical trials. Neurology. 2014 Aug;83(9):810-7. https://doi.org/10.1212/WNL.0000000000000741

6. Medrano S, Monges S, Gravina LP, Alías L, Mozzoni J, Aráoz HV, et al. Genotype-phenotype correlation of SMN locus genes in spinal muscular atrophy children from Argentina. Eur J Paediatr Neurol. 2016 Nov;20(6):910-7. https://doi.org/10.1016/j.ejpn.2016.07.017 
7. Godinho FMS, Bock H, Gheno TC, Saraiva-Pereira ML. Molecular analysis of spinal muscular atrophy: A genotyping protocol based on TaqMan(®) real-time PCR. Genet Mol Biol. 2012 Dec;35(4 suppl 14 (suppl)):955-9. https://doi.org/10.1590/S1415-47572012000600010

8. Monges S, Rosa AL. Management of neuromuscular diseases and spinal muscular atrophy in Latin America. Gene Ther. 2017 Sep;24(9):578-80. https://doi.org/10.1038/gt.2017.68

9. Encuesta Suplementaria de Ingresos 2016. Instituto Nacional de Estadísticas. [cited 2018 Aug 5]. Available from: http://www. ine.cl/docs/default-source/ingresos-y-gastos/esi/ingreso-dehogares-y-personas/resultados/2016/esi_sintesis_2016_nacional. pdf?sfvrsn $=4$

10. Bossert TJ, Leisewitz T. Innovation and change in the Chilean health system. N Engl J Med. 2016 Jan;374(1):1-5. https://doi.org/10.1056/NEJMp1514202

11. Castiglioni C, Levicán J, Rodillo E, Garmendia MA, Díaz A, Pizarro L, et al. [Clinical, electrophysiological and molecular study of 26 chilean patients with spinal muscular atrophy]. Rev Med Chil. 2011 Feb;139(2):197-204. Spanish. https://doi.org/10.4067/S0034-98872011000200009

12. Castillo Taucher S. Medical genetics and genomic medicine in Chile: opportunities for improvement. Mol Genet Genomic Med. 2015 Jul;3(4):243-7. https://doi.org/10.1002/mgg3.166

13. Miranda M, Bustamante ML. Commentary to medical genetics and genomic medicine in Chile: chilean experience on molecular diagnosis for neurodegenerative disorders. Mol Genet Genomic Med. 2017 May;5(4):305-6. https://doi.org/10.1002/mgg3.288

14. Finkel RS, Mercuri E, Darras BT, Connolly AM, Kuntz NL, Kirschner $J$, et a. Nusinersen versus Sham Control in Infantile-Onset Spinal Muscular Atrophy. N Engl J Med. 2017 Nov;377(18):1723-32. https://doi.org/10.1056/NEJMoa1702752

15. Mercuri E, Darras BT, Chiriboga CA, Day JW, Campbell C, Connolly AM, et al. Nusinersen versus sham control in later-onset spinal muscular atrophy. N Engl J Med. 2018 Feb;378(7):625-35. https://doi.org/10.1056/NEJMoa1710504

16. Mendell JR, Al-Zaidy S, Shell R, Arnold WD, Rodino-Klapac LR, Prior TW, et al. Single-dose gene-replacement therapy for spinal muscular atrophy. N Engl J Med. 2017 Nov;377(18):1713-22. https://doi.org/10.1056/NEJMoa1706198

17. Economic Cooperation and Development - OECD. Income inequality and poverty. In It Together. Why less inequality benefits all in Chile 2015 [cited 2018 Aug 5]. Available from: http://www.oecd.org/chile/ OECD2015-In-It-Together-Highlights-Chile.pdf

18. Febrer A, Vigo M, Fagoaga J, Medina-Cantillo J, Rodríguez N, Tizzano E. [Hammersmith functional rating scale for children with spinal muscular atrophy. Validation of the Spanish version]. Rev Neurol. 2011 Dec;53(11):657-63. Spanish.

19. Vuillerot C, Payan C, Iwaz J, Ecochard R, Bérard C. Responsiveness of the motor function measure in patients with spinal muscular atrophy. Arch Phys Med Rehabil. 2013 Aug;94(8):1555-61. https://doi.org/10.1016/j.apmr.2013.01.014

20. Finkel R, Bertini E, Muntoni F, Mercuri E. 209th ENMC International Workshop: Outcome Measures and Clinical Trial Readiness in Spinal Muscular Atrophy 7-9 November 2014, Heemskerk, The Netherlands. Neuromuscul Disord. 2015 Jul;25(7):593-602. https://doi.org/10.1016/j.nmd.2015.04.009
21. Ministry of Social Development (CH). Población.. [cited 2018 Aug 5]. Available from: http://www.ministeriodesarrollosocial.gob.cl/ipos/ pdf/ipos_2011_poblacion.pdf

22. Mercuri E, Finkel RS, Muntoni F, Wirth B, Montes J, Main M, et al. Diagnosis and management of spinal muscular atrophy: Part 1: Recommendations for diagnosis, rehabilitation, orthopedic and nutritional care. Neuromuscul Disord. 2018 Feb;28(2):103-15. https://doi.org/10.1016/j.nmd.2017.11.005

23. Instituto Nacional de Estad[isticasChile: Estadísticas vitales cifras provisionales 2017 . [cited 2018 Aug 5]. Available from https:// www.ine.cl/docs/default-source/demogr\%C3\%A1ficas-y-vitales/ vitales/anuarios/anuario-2017/estad\%C3\%ADsticas-vitales-cifrasprovisionales-2017.pdf?sfursn=da275ad2_4

24. Calvo A, Tartakowsky A, Maffei T.. Transformaciones en las estructuras familiars en Chile. 2011 [cited 2018 Aug 5]. Available from: http://www.ministeriodesarrollosocial.gob.cl/btca/ txtcompleto/mideplan/transformac.fam.chilenas.pdf

25. Lin CW, Kalb SJ, Yeh WS. Delay in Diagnosis of spinal muscular atrophy: a systematic literature review. Pediatr Neurol. 2015 Oct;53(4):293-300. https://doi.org/10.1016/j.pediatrneurol.2015.06.002

26. Wang $\mathrm{CH}$, Finkel RS, Bertini ES, Schroth M, Simonds A, Wong $\mathrm{B}$, et al. Consensus statement for standard of care in spinal muscular atrophy. J Child Neurol. 2007 Aug;22(8):1027-49. https://doi.org/10.1177/0883073807305788

27. Mazzone E, De Sanctis R, Fanelli L, Bianco F, Main M, Hauwe M, et al. Hammersmith functional motor scale and motor function measure-20 in non ambulant SMA patients. Neuromuscul Disord. 2014 Apr;24(4):347-52. https://doi.org/10.1016/j.nmd.2014.01.003

28. Bladen CL, Thompson R, Jackson JM, Garland C, Wegel C, Ambrosini A, et al. Mapping the differences in care for 5,000 spinal muscular atrophy patients, a survey of 24 national registries in North America, Australasia and Europe.J Neurol. 2014 Jan;261(1):152-63. https://doi.org/10.1007/s00415-013-7154-1

29. Catteruccia M, Vuillerot C, Vaugier I, Leclair D, Azzi V, Viollet L, et al. Orthopedic management of scoliosis by garches brace and spinal fusion in SMA Type 2 Children. J Neuromuscul Dis. 2015 Nov;2(4):453-62. https://doi.org/10.3233/JND-150084

30. Farrar MA, Park SB, Vucic S, Carey KA, Turner BJ, Gillingwater $\mathrm{TH}$, et al. Emerging therapies and challenges in spinal muscular atrophy. Ann Neurol. 2017 Mar;81(3):355-68. https://doi.org/10.1002/ana.24864

31. Finkel RS, Mercuri E, Meyer OH, Simonds AK, Schroth MK, Graham RJ, et al. Diagnosis and management of spinal muscular atrophy: Part 2: Pulmonary and acute care; medications, supplements and immunizations; other organ systems; and ethics. Neuromuscul Disord. 2018 Mar;28(3):197-207. https://doi.org/10.1016/j.nmd.2017.11.004

32. Finkel RS, Chiriboga CA, Vajsar J, Day JW, Montes J, De Vivo DC, et al. Treatment of infantile-onset spinal muscular atrophy with nusinersen: a phase 2, open-label, doseescalation study. Lancet. 2016 Dec;388(10063):3017-26. https://doi.org/10.1016/S0140-6736(16)31408-8

33. Groen EJ, Talbot K, Gillingwater TH. Advances in therapy for spinal muscular atrophy: promises and challenges. Nat Rev Neurol. 2018 Apr;14(4):214-24. https://doi.org/10.1038/nrneurol.2018.4 